\title{
Adeno-Associated Virus-Based Gene Therapy for Inherited Disorders
}

\author{
TERENCE R. FLOTTE \\ Department of Pediatrics, University of Florida, Box 100296, 1600 SW Archer Road, Gainesville, FL 32610
}

\begin{abstract}
ABSTR
Adeno-associated virus vectors are capable of long-term gene
transfer without obvious adverse effects in a number of animal
models. Over the last two decades, preclinical and early phase
clinical trials in cystic fibrosis and alpha-1 antitrypsin deficiency
were undertaken to test the feasibility of this approach. The
results of those studies have been important since they have
indicated that in vivo gene transfer is feasible and relatively safe.
In addition, a number of key limitations to the current generation
of AAV2 gene therapy vectors have been defined. The informa-
tion about these limitations has been used to develop newer AAV
vector approaches, based on new mutant and alternative serotype
\end{abstract}
The promise of gene therapy began with the identification of single genes responsible for autosomal recessive disorders like cystic fibrosis (CF) and alpha-1 antitrypsin (AAT) deficiency, and with the development of gene transfer vectors based on viruses capable of in vivo DNA transfer and gene expression. Over time, positive results from proof-of-concept studies in cell culture and animal models and the accumulation of preclinical safety data has led to the initiation of phase I and II clinical trials of recombinant adeno-associated virus serotype 2 (rAAV2)-CFTR and rAAV2-AAT gene therapy vectors. As these trials have progressed, much attention has been focused on potential safety issues, such as insertional mutagenesis, inadvertent germ line transmission, and immune responses to vector components and transgene products. To date, over 140 CF patients and 8 AAT deficient patients have been safely treated with rAAV2 vectors. No dramatic therapeutic benefits have yet been observed. However, important new information has been gained from both clinical and preclinical studies,

Received July 14, 2005; accepted July 15, 2005.

Correspondence: Terence R. Flotte, M.D., Department of Pediatrics, University of Florida, Box 100296, 1600 SW Archer Road, Gainesville, FL 32610-0296; e-mail: flotttr@peds.ufl.edu

Supported in part by grants from the NHLBI, NIDDK, NCRR, Cystic Fibrosis Foundation, and Alpha One Foundation. T.R.F. was the recipient of the Society for Pediatric Research 2005 E. Mead Johnson Award presented at the 2005 Annual Meeting of the Pediatric Academic Societies, Washington, D.C.

DOI: 10.1203/01.pdr.0000189226.03684.fe capsids and enhanced promoter systems. The evaluation of safety and efficacy of these newer agents is ongoing. (Pediatr Res 58: 1143-1147, 2005)

$\quad$ Abbreviations
AAT, alpha-1 antitryspin
AAV, adeno-associated virus
CF, cystic fibrosis
CFTR, cystic fibrosis transmembrane conductance regulator
rAAV, recombinant adeno-associated virus

which has informed the development of new vector strategies based on alternate rAAV serotypes. Simultaneously, gene transfer experiments have led to an improved understanding of the pathogenesis of the complex phenotypes associated with these disorders.

\section{AAV AND RECOMBINANT AAV VECTORS}

AAV is one of a relatively small group of viruses that have been successfully modified for use as gene transfer agents in human trials $(1-8)$. The properties of AAV that make it potentially useful for therapeutic gene transfer are listed in Table 1 . AAV is a $20-\mathrm{nm}$ diameter replication-deficient parvovirus (Fig. 1) native to humans and nonhuman primates and exists in nature in over 100 distinct variants, including both those defined serologically as serotypes and those defined by DNA sequence as genomovars (9-10). There is no consistent indication of AAV infection being associated with human disease, although adverse effects on early embryos have been suggested from ex vivo studies. Interestingly, many of the AAV serotypes have distinct cell and tissue affinities, potentially creating the option for generating a variety of different vector classes from this one genus of virus.

The life cycle of AAV has been studied in detail (11-12). Cells infected with AAV require a helper virus, such as an adenovirus, herpesvirus, or vaccinia virus, to replicate efficiently in cell culture. Cells infected with AAV alone usually harbor AAV genomes in a persistent or latent state. Latent 
Table 1. Properties of $A A V$ supporting its potential role in gene therapy

\section{Non-pathogenic}

Capable of persistent infection

Present in over 100 variants with diverse cell tropisms

Generally elicits mild innate cytokine response

Genome readily modified in proviral plasmids

Recombinant production and purification methods in place

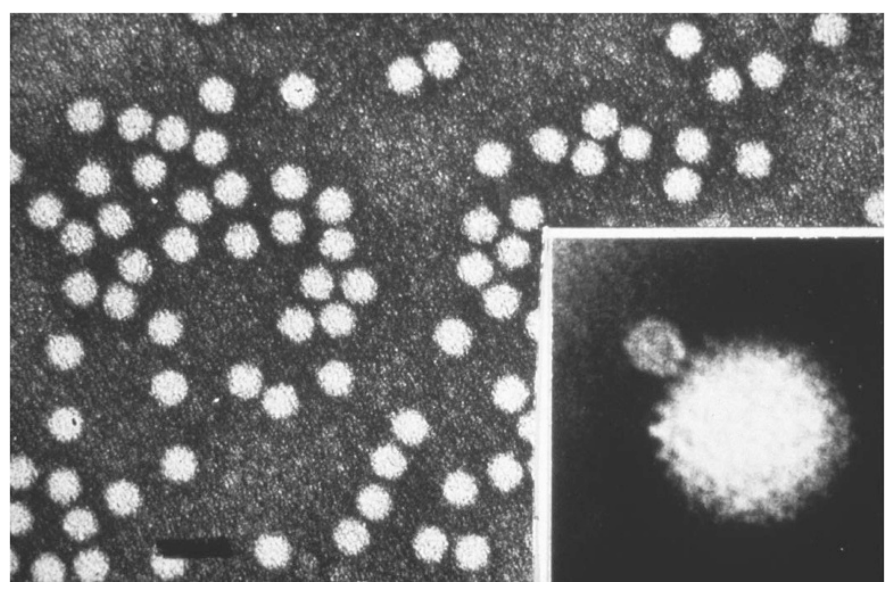

Figure 1. Electron micrograph of AAV2 particles. The broader field shows purified wild-type AAV2 particles. The inset shows a side-by-side micrograph of an AAV2 particle and an Adenovirus type 5 particle. (Reproduced with permission from Flotte et al. 1996 Hum Gene Ther 7:1145-1159. () Mary Ann Liebert, Inc.)

AAV genomes exist in a number of forms including episomal forms, randomly integrated forms, and forms that are integrated site-specifically into a region of human chromosome 19 known as the AAVS1 site (13-18). The $4.7 \mathrm{~kb}$ AAV genome mediates all of these functions with only 2 genes, the cap gene, which encodes the $3 \mathrm{AAV}$ capsid proteins, and the rep gene, which encodes the four nonstructural Rep proteins, which are required for viral replication and site-specific integration. Flanking the AAV genes are the inverted terminal repeats (ITRs), which contain the cis-acting sequences required for DNA replication and packaging. Sequences within the ITR also have transcription regulatory activity, including enhancer function and a low efficiency promoter function.

Recombinant AAV vectors based on the most frequently studied serotype, AAV2, were produced in the mid-1980s by creating ITR-deleted helper plasmids to supply rep and cap functionsm (19-21). Recombinant AAV2 vector plasmids were also constructed in which ITR-sequences flanked the therapeutic gene of interest, along with an appropriate promoter and polyadenylation signal. When helper plasmids and vector plasmids were co-transfected into permissive cells (usually human embryonic kidney 293 cells) that were also infected with a helper adenovirus, those cells packaged rAAV2 virions containing only the therapeutic vector genomes. Vector particles, thus produced, could be purified using $\mathrm{CsCl}$ density gradient ultacentrifugation. Over time, rAAV2 packaging and purification technology has improved, and helper plasmids now most frequenly encode both adenovirus and AAV helper genes. Recombinant vector particles are often purified using column chromatography methods and/or nonionic gradient media, resulting in a higher level of infectivity of recombinant virus as well as higher overall titers (22).

\section{RECOMBINANT AAV2 VECTORS FOR CYSTIC FIBROSIS (CF) GENE THERAPY}

CF was one of the first human diseases targeted for gene therapy with rAAV vectors. Early work focused on defining small endogenous promoter elements within the left-hand end of the AAV genome that could be used to express the relatively large coding sequence of the $\mathrm{CF}$ transmembrane conductance regulator (CFTR) gene $(4.44 \mathrm{~kb})$ within the limited packaging capacity of this small virus (approximately $5 \mathrm{~kb}$ packaging limit) (23-24). Since $0.3 \mathrm{~kb}$ was required for the two AAV2ITRs, there was relatively little space available for exogenous promoter elements. Vectors expressing reporter genes or CFTR from compact elements in or near the AAV2-ITR were produced and shown to mediate the typical cAMP-activated chloride currents characteristic of CFTR expression (Fig. 2), as well as restoring regulation of other ion channels in airway epithelial cells, such as the outwardly rectifying chloride channel (25).

Preclinical studies demonstrated that rAAV vectors were capable of long-term gene transfer and expression in the bronchial epithelium of rabbits and nonhuman primates, despite the fact that vector genomes appeared to persist predominantly in the episomal state (26-29). Importantly, studies also demonstrated no increase in inflammatory cells, or proinflammatory cytokines after rAAV delivery to the lower airways of nonhuman primates. Likewise, there were no adverse changes in chest $\mathrm{x}$-rays, arterial blood gases, or pulmonary function tests in these animals after rAAV delivery. Based on this information, a number or phase I and phase II clinical trials of rAAV2-CFTR were performed.

Phase I clinical trials of rAAV2-CFTR included studies of nasal and endobronchial instillation, direct instillation into the

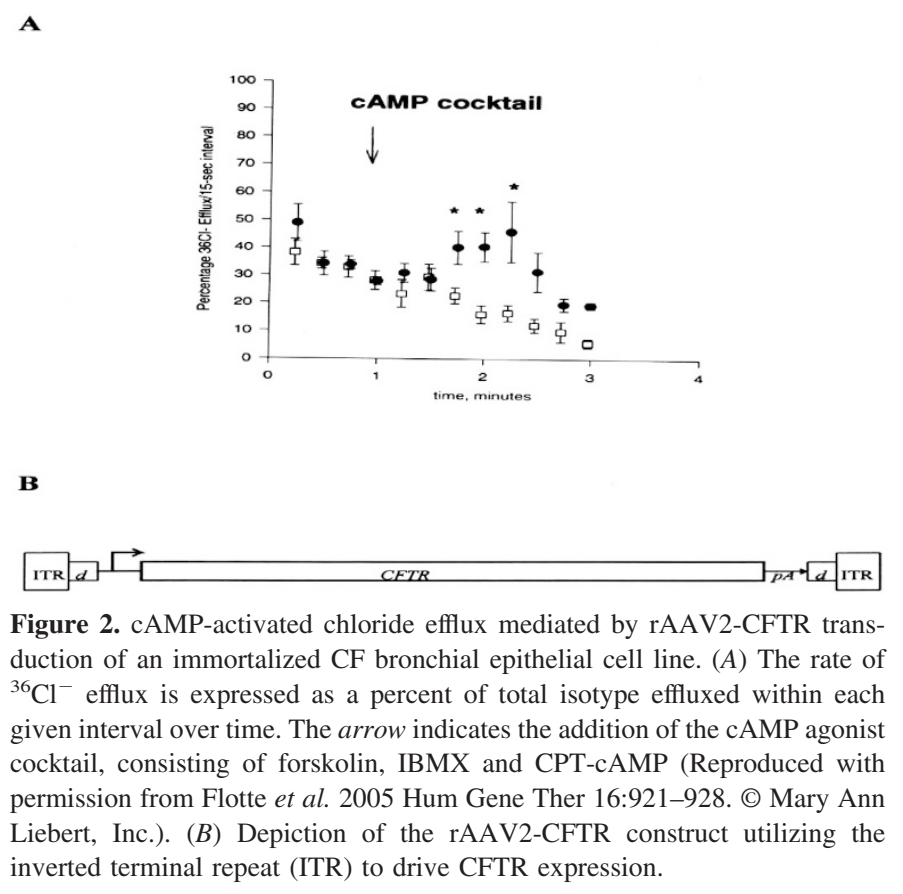


maxillary sinuses, and aerosol inhalation (1-8). These studies showed definite evidence of dose-related DNA transfer, and some indication of gene expression. Subsequent phase II studies of aerosol inhalation of rAAV2-CFTR have indicated again that gene transfer and its effects are detectable for approximately $30 \mathrm{~d}$ after the initial instillation (Fig. 3). Altogether over $200 \mathrm{CF}$ patients participated in these trials, with over 140 receiving active vector. There was no consistent indication of vector-related adverse effects from any of these studies. Unfortunately, neutralizing antibodies were also detected and repeated doses did not show evidence of repeated efficient gene transfer. The shorter duration of gene transfer in the human studies may be due to an accelerated turnover of bronchial epithelium in the context of the diseased CF lung.

During the course of these studies a number of key limitations of the rAAV2-CFTR vector technology came to light, some from these studies directly and others from the work of other investigators. Some of these key limitations are listed in Table 2. The efficiency of gene transfer and expression appear to have been limited by the relatively low abundance of the typical AAV2 receptor (heparan sulfate proteoglycan) and its co-receptors (alphaV-beta5 integrin, and FGF-receptor) on the apical surface of the airways and by the relative inefficiency of the AAV-ITR promoter (30-32). Both of these were relative limitations, however, as indicated by recent data from a tracheal xenograft model in which an alternative receptor pathway that is more susceptible to proteasome-mediated degradation has been defined (33). When this pathway is blocked, the efficiency of gene transfer with the original rAAV2-ITRpromoter driven vector was comparable with newer vectors. Nonetheless, this inefficiency was compounded by inactivation of rAAV2 particles by extracellular barriers, including neutrophil elastase, neutrophil-derived alpha defensins, and other substances (34). The ultimate problem, however, appears to have been the short duration of gene transfer, which apparently related to the more rapid turnover of the $\mathrm{CF}$ airway epithelium with the subsequent loss of episomal rAAV genomes. The development of neutralizing antibodies by patients in these studies correlated with an inability to observe repeated positive results with repeated administrations of the vector.

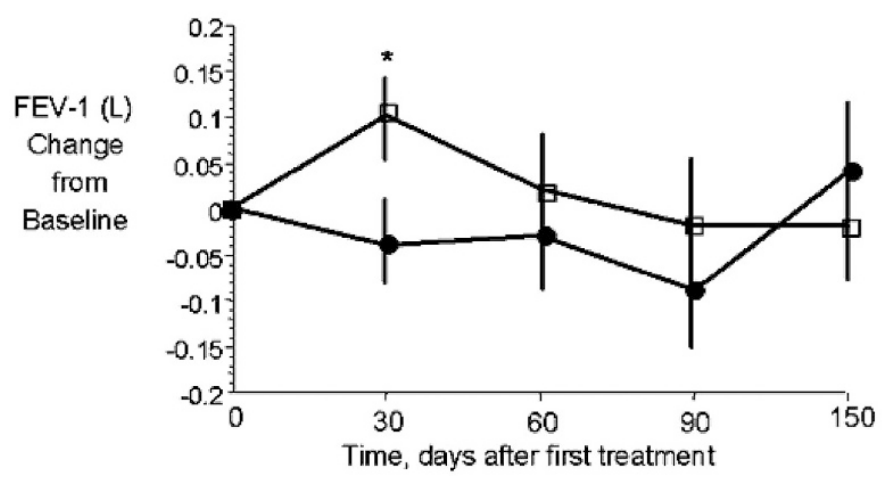

Figure 3. Evidence of efficacy of rAAV2-CFTR gene transfer in a prospective, double-blinded, placebo-controlled trial. Plotted are the changes from baseline in FEV-1 in liters, in vector-treated ( $n=20$, open squares) and placebo controls $(n=17$, closed circles $)$. The asterisk indicates a significant difference at $p<0.04$. [Adapted from Moss et al. 2004 Chest 125:509-521 (C) American College of Chest Physicians, with permission).
Table 2. Key limitations of rAAV2-CFTR vector technology

Relative paucity of AAV2 receptors and co-receptors on luminal surface of airway

Inefficiency of the ITR promoter

Inactivation of rAAV2 within the CF airway (elastase, alpha defensins, mucus, glycocalyx)

Rapid turnover of CF airway epithelium limiting the persistence of rAAV2 episomes

Development of neutralizing anti-AAV2 antibodies limiting the efficiency or repeated dosing

\section{DEVELOPMENT OF THE NEXT GENERATION OF rAAV-CFTR: rAAV5-CB-dl264 CFTR}

Based on the information gleaned from these trials and other developments in the field, newer generations of rAAV-CFTR have been developed by a number of groups. One such agent combines the newly available serotype 5 capsid (actually a pseudotype, since the AAV2-ITRs are present in the vector DNA cassette), a large very efficient CMV/beta actin (CB) hybrid promoter, and a minigene version of CFTR that omits sequences that are not necessary for CAMP-activated chloride channel activity (35). The serotype 5 capsid targets alternative receptors present in higher abundance in the $\mathrm{CF}$ airways, and may avoid neutralizing antibodies to AAV2. The more active promoter will assure a greater level of mRNA expression within each transduced cell, while the CFTR minigene allows sufficient capacity within the vector for the promoter to be efficiently packaged.

Recently published studies with the rAAV5-CB-dl264CFTR indicate that it is capable of high level expression of CFTR chloride currents in cell lines, and ameloriation of the lung inflammation and weight loss phenotypes of CFTR knock-out mice that are exposed to a Pseudomonas-agarose bead slurry (Fig. 4). This vector type also has shown an increase in the efficiency of gene transfer in larger animal models.

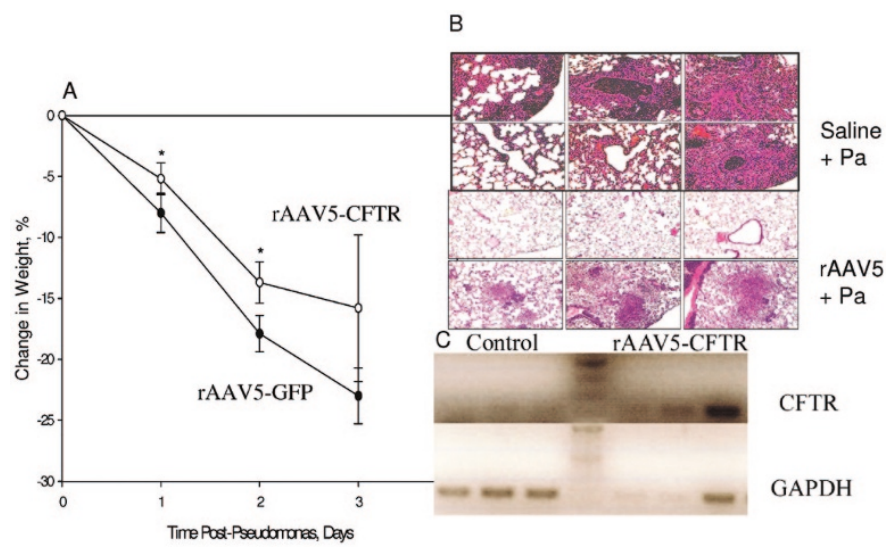

Figure 4. Protective effect of rAAV5-CFTR on weight loss and lung inflammation in a Pseudomonas-agarose bead-infected CFTR knockout mouse model. (Reproduced with permission from Sirninger et al. 2004 Hum Gene Ther 15:832-841. (C) Mary Ann Liebert, Inc.) (A) Amelioration of weight loss after challenge with Pseudomonas in rAAV5-CFTR vector treated $v s$. GFPvector treated controls. (B) Amelioration of Pseudomonas-induced lung inflammation with rAAV5-CFTR as compared with controls. (C) RT-PCR demonstration of CFTR mRNA expression in vector-treated mouse lung homogenates. 


\section{RECOMBINANT AAV VECTORS FOR GENE THERAPY OF AAT DEFICIENCY}

One of the key limitations of rAAV vectors learned from the preclinical and clinical studies associated with the $\mathrm{CF}$ gene therapy effort, was the finding that the majority of vector genomes were episomal, thus limiting their persistence in the steadily proliferating CF bronchial epithelium. Diseases due to deficiencies of secreted proteins might not share that problem, however, since nonproliferating cells might be targeted for gene transfer. One such disease of interest is alpha-1 antitrypsin (AAT) deficiency. The frequency of AAT mutation in the population is similar to that seen with $\mathrm{CF}$, approximately $4 \%$. AAT deficiency is more genetically homogeneous than $\mathrm{CF}$, however, with $>95 \%$ of mutant alleles being represented by the so-called $\mathrm{Z}$ allele. This missense mutation leads to a defect in secretion of this important $52 \mathrm{kD}$ antiprotease from hepatocytes into the circulation. A lack of AAT results in long-term loss of pulmonary interstitial elastin, due to the unopposed action of neutrophil elastase and other neutrophil products. The loss of interstitial elastin and chronic airway inflammation lead to a form of chronic obstructive pulmonary disease that is typically diagnosed in adulthood. Genotype-phenotype and protein replacement experience suggests that lung disease risk is much reduced if plasma AAT levels are above 11 micromolar (570-800 $\mu \mathrm{g} / \mathrm{mL} ; 57-80 \mathrm{mg} / \mathrm{dL})$ (36). The goal of gene therapy for AAT lung disease is, therefore, to substitute for protein replacement in expressing levels in that range.

The potential utility of rAAV2-mediated transduction of skeletal muscle as a site for ectopic AAT secretion was described in a number studies from the late 1990s in which the biologic efficacy of rAAV2 vectors and the efficiency of secretion were noted (37-40) demonstrated that a single IM dose of rAAV2-AAT in C57B16 mice resulted in levels of AAT that would be therapeutic in humans (Fig. 5). Interestingly, C57B16 mice were tolerant for human AAT, while many other mouse strains were not, apparently due to immunologic differences. Even more serendipitous was the observation that another immunologic control strain for these experiments, a DNAdependent protein kinase (DNA-PK)-deficient severe com-

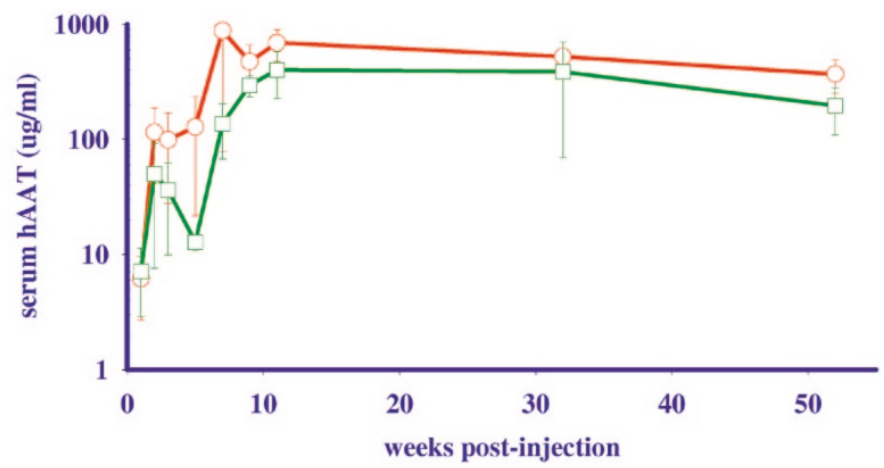

Figure 5. Sustained serum levels of human AAT after intramuscular injection of rAAV2-AAT. (Reproduced with permission from Song et al. 2001 Proc Natl Acad Sci U S A 98:4084-4088 (C) The National Academy of Sciences of the USA). Serum levels of hAAT in mice after a single IM injection of $1.4 \times$ $10^{13}$ vector genome particles per mouse in SCID (open circles) or C57B16 mice (open squares) bined immune deficiency (SCID) mouse model was also readily transduced by $\mathrm{rAAV} 2-\mathrm{hAAT}$, but resulted in a predominance of integrated vector forms long-term (41). This stood in contrast to C57B16 mice, which demonstrated predominantly episomal persistence. This finding was later reproduced with liver delivery of rAAV2-AAT (42). The latter approach had the added feature of allowing for more sensitive and specific differentiation between episomal and integrated forms. Further data indicated in a cell-free system, that DNA-PK, a critical component of the ligase used for DNA double-strand break repair and VDJ recombination both inhibited rAAV2 integration and promoted the formation of episomal vector-to-vector junctions.

These studies not only established the proof-of-concept for IM rAAV2-AAT gene therapy trials in humans, but also pointed out that the episomal pool of vector genomes that predominates with rAAV2 vectors is formed by an active process that requires the activity of host cell factors, like DNA-PK. Further preclinical studies were performed in C57B16 mice and New Zealand White rabbits to better define the potential for inadvertent germline transmission or other vector-related adverse effects (43). Based on that information a phase I study of rAAV2-AAT IM injection in C57B16 mice has been initiated. This ongoing study will include doses up to approximately $7 \times 10^{13}$ vector genomes per patient (7). At the same time, critical proof-of-concept and safety data are being generated with a rAAV1-pseudotyped rAAV-AAT vector, a vector which mediates 500-fold greater gene transfer efficiency in recent studies (44).

\section{SUMMARY AND FUTURE DIRECTIONS}

The development of rAAV2 vectors for CF and AAT deficiency has resulted in a number of key findings, including an excellent safety record through experience with over a thousand animals and nearly 150 human patients. In addition to the short-term safety of this class of vector, an important series of studies suggest that the risk of insertional mutagenesis with this vector class is likely to be smaller than that seen with retrovirus vectors, since the majority of rAAV genomes are episomal and since this episomal persistence is mediated by a specific DNA-PK dependent host-cell pathway. The efficacy data with rAAV2 vectors has been more modest. However, the advent of newer rAAV serotypes has opened the possibility that lessons learned from the early years of CF and AAT gene therapy will be salient to the development of later generations of AAV vectors that have enhanced efficacy, while retaining the important safety features of this vector.

Recent years have also witnessed an extensive expansion of the use of these vectors to other diseases, particularly genetic and metabolic disorders involving the muscle, liver, and CNS. Recombinant AAV vectors have also been used to model and complement important animal models that better mimic the human phenotypes of these disorders. The combination of better animal models and improved biologic efficacy support the concept that in the future, safe and effective rAAVmediated gene transfer methods will be devised. 


\section{REFERENCES}

1. Flotte T, Carter B, Conrad C, Guggino W, Reynolds T, Rosenstein B, Taylor G, Walden S, Wetzel R 1996 A phase I study of an adeno-associated virus-CFTR gene vector in adult $\mathrm{CF}$ patients with mild lung disease. Hum Gene Ther 7:1145-1159

2. Flotte TR, Carter BJ 1998 Adeno-associated virus vectors for gene therapy of cystic fibrosis. Methods Enzymol 292:717-732

3. Wagner JA, Moran ML, Messner AH, Daifuku R, Conrad CK, Reynolds T, Guggino WB, Moss RB, Carter BJ, Wine JJ, Flotte TR, Gardner P 1198 A phase I/II study of $\operatorname{tg}$ AAV-CF for the treatment of chronic sinusitis in patients with cystic fibrosis. Hum Gene Ther 9:889-909.

4. Wagner JA, Messner AH, Moran ML, Daifuku R, Kouyama K, Desch JK, Manley S, Norbash AM, Conrad CK, Friborg S, Reynolds T, Guggino WB, Moss RB, Carter BJ Wine JJ, Flotte TR, Gardner P 1999 Safety and biological efficacy of an adenoassociated virus vector-cystic fibrosis transmembrane regulator (AAV-CFTR) in the cystic fibrosis maxillary sinus. Laryngoscope 109:266-274

5. Flotte TR, Zeitlin PL, Reynolds TC, Heald AE, Pedersen P, Beck S, Conrad CK, Brass-Ernst L, Humphries M, Sullivan K, Wetzel R, Taylor G, Carter BJ, Guggino WB 2003 Phase I trial of intranasal and endobronchial administration of a recombi nant adeno-associated virus serotype 2 (rAAV2)-CFTR vector in adult cystic fibrosis patients: a two-part clinical study. Hum Gene Ther 14:1079-1088

6. Wagner JA, Nepomuceno IB, Messner AH, Moran ML, Batson EP, Dimiceli S, Brown BW, Desch JK, Norbash AM, Conrad CK, Guggino WB, Flotte TR, Wine JJ, Carter BJ, Reynolds TC, Moss RB, Gardner P 2002 A phase II, double-blind, randomized, placebo-controlled clinical trial of tgAAVCF using maxillary sinus delivery in patients with cystic fibrosis with antrostomies. Hum Gene Ther 13:13491359

7. Flotte TR, Brantly ML, Spencer LT, Byrne BJ, Spencer CT, Baker DJ, Humphries M 2004 Phase I trial of intramuscular injection of a recombinant adeno-associated virus alpha 1-antitrypsin (rAAV2-CB-hAAT) gene vector to AAT-deficient adults. Hum Gene Ther 15:93-128

8. Moss RB, Rodman D, Spencer LT, Aitken ML, Zeitlin PL, Waltz D, Milla C, Brody AS, Clancy JP, Ramsey B, Hamblett N, Heald AE 2004 Repeated adeno-associated virus serotype 2 aerosol-mediated cystic fibrosis transmembrane regulator gene transfer to the lungs of patients with cystic fibrosis: a multicenter, double-blind, placebo-controlled trial. Chest 125:509-521

9. Gao GP, Alvira MR, Wang L, Calcedo R, Johnston J, Wilson JM. 2002 Nove adeno-associated viruses from rhesus monkeys as vectors for human gene therapy. Proc Natl Acad Sci U S A 99:11854-11589

10. Gao G, Vandenberghe LH, Alvira MR, Lu Y, Calcedo R, Zhou X, Wilson JM 2004 Clades of Adeno-associated viruses are widely disseminated in human tissues. J Virol 78:6381-6388

11. Berns KI, Linden RM 1995 The cryptic life style of adeno-associated virus. Bioessays 17:237-245

12. Berns KI. 1996 Parvoviridae: the viruses and their replication. In: Fields BN, Knipe DM, Howley PM (eds) Fields Virology. Raven Press, Philadelphia, pp 2173-2197

13. Kotin RM, Berns KI 1989 Organization of adeno-associated virus DNA in latently infected Detroit 6 cells. Virology 170:460-467

14. Kotin RM, Siniscalco M, Samulski RJ, Zhu XD, Hunter L, Laughlin CA, McLaughlin S, Muzyczka N, Rocchi M, Berns KI 1990 Site-specific integration by adenoassociated virus. Proc Natl Acad Sci U S A 87:2211-2215

15. Kotin RM, Menninger JC, Ward DC, Berns KI 1991 Mapping and direct visualization of a region-specific viral DNA integration site on chromosome 19q13-qter. Genomics 10:831-834

16. Kotin RM, Linden RM, Berns KI 1992 Characterization of a preferred site on human chromosome 19q for integration of adeno-associated virus DNA by non-homologous recombination. EMBO J 11:5071-5078

17. Samulski RJ 1993 Adeno-associated virus: integration at a specific chromosomal locus. Curr Opin Genet Dev 3:74-80

18. Samulski RJ, Zhu X, Xiao X, Brook JD, Housman DE, Epstein N, Hunter LA 1991 Targeted integration of adeno-associated virus (AAV) into human chromosome 19 EMBO J 10:3941-3950. Erratum in: EMBO J 1992 11:1228-

19. Tratschin JD, West MH, Sandbank T, Carter BJ 1984 A human parvovirus, adenoassociated virus, as a eucaryotic vector: transient expression and encapsidation of the procaryotic gene for chloramphenicol acetyltransferase. Mol Cell Biol 4:2072-2081

20. Tratschin JD, Miller IL, Smith MG, Carter BJ 1985 Adeno-associated virus vector fo high-frequency integration, expression, and rescue of genes in mammalian cells. Mol Cell Biol 5:3251-3260

21. Hermonat PL, Muzyczka N 1984 Use of adeno-associated virus as a mammalian DNA cloning vector: transduction of neomycin resistance into mammalian tissue culture cells. Proc Natl Acad Sci U S A 81:6466-6670
22. Zolotukhin S, Byrne BJ, Mason E, Zolotukhin I, Potter M, Chesnut K, Summerford C, Samulski RJ, Muzyczka N 1999 Recombinant adeno-associated virus purification using novel methods improves infectious titer and yield. Gene Ther 6:973-985

23. Flotte TR, Solow R, Owens RA, Afione S, Zeitlin PL, Carter BJ 1992 Gene expression from adeno-associated virus vectors in airway epithelial cells. Am J Respir Cell Mol Biol 7:349-356

24. Flotte TR, Afione SA, Solow R, Drumm ML, Markakis D, Guggino WB, Zeitlin PL, Carter BJ 1993 Expression of the cystic fibrosis transmembrane conductance regulator from a novel adeno-associated virus promoter. J Biol Chem 268:3781-3790

25. Egan M, Flotte T, Afione S, Solow R, Zeitlin PL, Carter BJ, Guggino WB 1992 Defective regulation of outwardly rectifying $\mathrm{Cl}$ - channels by protein kinase A corrected by insertion of CFTR. Nature 358:581-584

26. Flotte TR, Afione SA, Conrad C, McGrath SA, Solow R, Oka H, Zeitlin PL, Guggino WB, Carter BJ 1993 Stable in vivo expression of the cystic fibrosis transmembrane conductance regulator with an adeno-associated virus vector. Proc Natl Acad Sci U S A 90:10613-10617

27. Flotte TR, Afione SA, Zeitlin PL 1994 Adeno-associated virus vector gene expression occurs in nondividing cells in the absence of vector DNA integration. Am J Respir Cell Mol Biol 11:517-521

28. Afione SA, Conrad CK, Kearns WG, Chunduru S, Adams R, Reynolds TC, Guggino WB, Cutting GR, Carter BJ, Flotte TR 1996 In vivo model of adeno-associated virus vector persistence and rescue. J Virol 70:3235-3241

29. Conrad CK, Allen SS, Afione SA, Reynolds TC, Beck SE, Fee-Maki M, BarrazzaOrtiz X, Adams R, Askin FB, Carter BJ, Guggino WB, Flotte TR 1996 Safety of single-dose administration of an adeno-associated virus (AAV)-CFTR vector in the primate lung. Gene Ther 3:658-668

30. Teramoto S, Bartlett JS, McCarty D, Xiao X, Samulski RJ, Boucher RC 1998 Factors influencing adeno-associated virus-mediated gene transfer to human cystic fibrosis airway epithelial cells: comparison with adenovirus vectors. J Virol 72:8904-12

31. Summerford C, Samulski RJ 1999 Membrane-associated heparan sulfate proteoglycan is a receptor for adeno-associated virus type 2 virions. J Virol 72:1438-1445

32. Summerford C, Bartlett JS, Samulski RJ 1999 AlphaVbeta5 integrin: a co-receptor for adeno-associated virus type 2 infection. Nat Med 5:78-82

33. Yan Z, Zak R, Zhang Y, Ding W, Godwin S, Munson K, Peluso R, Engelhardt JF 2004 Distinct classes of proteasome-modulating agents cooperatively augment recombinant adeno-associated virus type 2 and type 5-mediated transduction from the apical surfaces of human airway epithelia. J Virol 78:2863-2874

34. Virella-Lowell I, Poirier A, Chesnut KA, Brantly M, Flotte TR 2000 Inhibition of recombinant adeno-associated virus (rAAV) transduction by bronchial secretions from cystic fibrosis patients. Gene Ther 7:1783-1789

35. Sirninger J, Muller C, Braag S, Tang Q, Yue H, Detrisac C, Ferkol T, Guggino WB, Flotte TR 2004 Functional characterization of a recombinant adeno-associated virus 5 -pseudotyped cystic fibrosis transmembrane conductance regulator vector. Hum Gene Ther 15:832-841

36. Crystal RG 1989 The alpha 1-antitrypsin gene and its deficiency states. Trends Genet 5:411-417

37. Kessler PD, Podsakoff GM, Chen X, McQuiston SA, Colosi PC, Matelis LA, Kurtzman GJ, Byrne BJ 1996 Gene delivery to skeletal muscle results in sustained expression and systemic delivery of a therapeutic protein. Proc Natl Acad Sci U S A 26:14082-14087

38. Xiao X, Li J, Samulski RJ 1996 Efficient long-term gene transfer into muscle tissue of immunocompetent mice by adeno-associated virus vector. J Virol 70:8098-8108

39. Fisher KJ, Jooss K, Alston J, Yang Y, Haecker SE, High K, Pathak R, Raper SE, Wilson JM 1997 Recombinant adeno-associated virus for muscle directed gene therapy. Nat Med 3:306-312

40. Song S, Morgan M, Ellis T, Poirier A, Chesnut K, Wang J, Brantly M, Muzyczka N, Byrne BJ, Atkinson M, Flotte TR 1998 Sustained secretion of human alpha-1antitrypsin from murine muscle transduced with adeno-associated virus vectors. Proc Natl Acad Sci U S A 95:14384-14388

41. Song S, Laipis PJ, Berns KI, Flotte TR 2001 Effect of DNA-dependent protein kinase on the molecular fate of the rAAV2 genome in skeletal muscle. Proc Natl Acad Sci U S A 98:4084-4088

42. Song S, Lu Y, Choi YK, Han Y, Tang Q, Zhao G, Berns KI, Flotte TR 2004 DNA-dependent PK inhibits adeno-associated virus DNA integration. Proc Natl Acad Sci U S A 101:2112-2116

43. Poirier A, Campbell-Thompson M, Tang Q, Scott-Jorgensen M, Combee L, Loiler S, Crawford J, Song S, Flotte TR 2004 Toxicology and biodistribution studies of recombinant adeno-associated virus 2-alpha-1 antitrypsin vector. Preclinica 2:43-51

44. Chao H, Liu Y, Rabinowitz J, Li C, Samulski RJ, Walsh CE 2000 Several log increase in therapeutic transgene delivery by distinct adeno-associated viral serotype vectors. Mol Ther 2:619-623 